\title{
Article \\ Effect of Ti Addition on the Precipitation Mechanism and Precipitate Size in Nb-Microalloyed Steels
}

\author{
Jun Xing ${ }^{1,2}$, Guohui Zhu ${ }^{1}$, Baoqiao Wu ${ }^{2}$, Hanlin Ding ${ }^{3, *}$ and Hongbo Pan ${ }^{1}$ \\ 1 School of Metallurgy Engineering, Anhui University of Technology, Ma'anshan 243000, China; \\ xingjun7036@163.com (J.X.); zhugh@ahut.edu.cn (G.Z.); panhb718@163.com (H.P.) \\ 2 Masteel Branch, Academia Sinica, Baowu Group, Ma'anshan 243000, China; wbq_mail@163.com \\ 3 School of Iron and Steel, Soochow University, Suzhou 215006, China \\ * Correspondence: dinghanlin@suda.edu.cn
}

check for

updates

Citation: Xing, J.; Zhu, G.; Wu, B.; Ding, H.; Pan, H. Effect of Ti Addition on the Precipitation Mechanism and Precipitate Size in $\mathrm{Nb}$-Microalloyed Steels. Metals 2022, 12, 245. https://doi.org/10.3390/ met12020245

Academic Editor: José María Rodríguez-lbabe

Received: 4 January 2022

Accepted: 25 January 2022

Published: 27 January 2022

Publisher's Note: MDPI stays neutral with regard to jurisdictional claims in published maps and institutional affiliations.

Copyright: (C) 2022 by the authors. Licensee MDPI, Basel, Switzerland. This article is an open access article distributed under the terms and conditions of the Creative Commons Attribution (CC BY) license (https:// creativecommons.org/licenses/by/ $4.0 /)$.

\begin{abstract}
The effect of Ti microalloying on the precipitation of $\mathrm{NbC}$ particles in $\mathrm{Nb}$-microalloyed and $\mathrm{Nb}$-Ti-microalloyed steels was investigated by scanning transmission electron microscopy. The experimental results illustrate that $\mathrm{NbC}$ precipitates tend to be formed via a conventional "nucleation and growth" mechanism in Ti-free steel, while the particles would be precipitated as a complex form of TiN cuboid core and $\mathrm{NbC}$ hemispherical cap in Ti-Nb-microalloyed steel with $0.009 \mathrm{wt}$ \% Ti and $0.0046 \mathrm{wt} . \% \mathrm{~N}$. Ti microalloying contributed to the refinement of the precipitate size, and an enhancement of the volume fraction of $\mathrm{NbC}$ particles was also found based on the experimental observations.
\end{abstract}

Keywords: Ti-microalloying; precipitation mechanism; epitaxial growth; refinement of precipitates

\section{Introduction}

Structural steels with heavy thickness are commonly used in complex constructions, such as offshore oil platforms, large-scale bridges and so on [1-3], which usually operate in low-temperature environments. To meet the safety requirements [4-6], high strength as well as excellent toughness are necessary for heavy structural steels. It has been reported that very fine and homogeneous grains are beneficial for simultaneously improving strength and toughness. Thermomechanical control processing (TMCP) has been proven to be an effective approach to the achievement of fine grains and has been widely applied in the manufacturing of hot rolled steels, in which sufficient strain accumulation before phase transformation is generally considered to be an essential issue $[7,8]$. However, it is always a challenge for heavy structural steels, because their limited reduction during the hot rolling process cannot bring about enough strain accumulation for the stimulation of a "strain-induced phase transformation" to refine the grain size.

To control the grain size in heavy structural steels, a new method named the "boundaryinduced transformation (BIT)" mechanism [9-11] has been proposed, in which abundant austenite grain boundaries are reasonably used to promote the nucleation of thephase transformation from austenite to ferrite. Obviously, whether the BIT mechanism can be realized or not depends strongly on the achievement of fine austenite grains during finish rolling. Therefore, compared to conventional $\mathrm{TMCP}$, how to adjust the critical strain for dynamic recrystallization (DRX) and how to use the limited reduction ratio effectively become the key factors for this method. The investigation in our previous work shows that Ti microalloying is conducive to the grain refinement of heavy structural steels [12]. The primary reason for grain refinement can be attributed to the advantage of the inhibitory effect of TiN precipitates on grain growth during reheating before rough rolling.

Much work has been carried out on the effect of Ti addition on the size of TiN particles, and the results in most steels showed that TiN particles formed during solidification or in the heat-affected zone usually have cuboidal shapes and relatively large sizes at the micron level [13-15]. Obviously, such TiN particles formed from the liquid phase cannot play any 
role in the improvement of the mechanical properties of the final product, while those precipitated in the solid phase usually have a fine size at the nanometer level [16], which is beneficial for the control of austenite grain size and contributes to the improvement of mechanical properties.

In addition, fine TiN particles acting as nucleation cores for $\mathrm{NbC}$ particles and resulting in the formation of $\mathrm{TiN}-\mathrm{NbC}$ composites during subsequent finish rolling have also been reported $[17,18]$. This phenomenon offers an alternative approach to strain-induced precipitation of $\mathrm{NbC}$, which can be reasonably utilized for the microstructural control of heavy structural steels with limited strain accumulation. However, the effect of Ti microalloying on the size and distribution of $\mathrm{NbC}$ has not been reported. In the present work, the precipitation behaviour of $\mathrm{NbC}$ particles and the precipitate size in Ti-free and Ti-microalloyed steels were investigated in detail. The results are useful for considering the control of microstructure and mechanical properties for heavy structural steels with limited reduction ratios and low $\mathrm{Nb}$ contents.

\section{Experimental Materials and Methods}

The chemical compositions of the heavy hot-rolled H-beam steels used in the present research are shown in Table 1. Experimental steel S1 is Nb-microalloyed steel, in which trace amounts of Ti element of approximately $0.002 \mathrm{wt} . \%$ are introduced due to the raw materials during steelmaking. Steel S2 is Ti- and Nb-microalloyed steel, in which a Ti addition of approximately $0.009 \mathrm{wt} . \%$ is adapted with the aim of evaluating the influence of the Ti element. The $\mathrm{N}$ contents in both steels are approximately $40 \mathrm{ppm}$.

Table 1. Chemical composition of the experimental steels (wt.\%).

\begin{tabular}{ccccccccccc}
\hline Steels & $\mathbf{C}$ & $\mathbf{M n}$ & $\mathbf{S i}$ & $\mathbf{P}$ & $\mathbf{S}$ & $\mathbf{T i}$ & $\mathbf{N b}$ & $\mathbf{V}$ & $\mathbf{A l}$ & $\mathbf{N}$ \\
\hline S1 & 0.18 & 1.51 & 0.54 & 0.006 & 0.003 & 0.002 & 0.031 & 0.023 & 0.012 & 0.0047 \\
S2 & 0.12 & 1.49 & 0.31 & 0.004 & 0.003 & 0.009 & 0.038 & 0.034 & 0.013 & 0.0046 \\
\hline
\end{tabular}

The experimental steels were forged according to the deformation process schematically shown in Figure 1. The total compression ratio during forging was approximately 2.5. The specimens, with sizes of $10 \mathrm{~mm} \times 10 \mathrm{~mm} \times 10 \mathrm{~mm}$, were cut from forged billets for the observation of precipitates. The forged specimens were mechanically polished and etched in a solution of $5 \%$ natal. The cellulose acetate film, with a thickness of $100 \mu \mathrm{m}$, was attached onto the etched specimens using acetone, and then the dried cellulose acetate films were extracted from the specimen surfaces. The carbon was evaporated onto these acetate films in a vacuum atmosphere. The carbon replicas were achieved by dissolving cellulose acetate films in acetone, and then moved onto a copper grid. Carbon extraction replicas were then applied to investigate the morphology and size of precipitates by a JEOL JEM 2100F field emission transmission electron microscope (TEM, JEOL Ltd., Tokyo, Japan), OXFORD X-MAX TSR energy dispersive spectroscopy (EDS, Oxford Instruments, Oxford, United Kingdom), and a high-resolution FEI Titan scanning transmission electron microscope (STEM, FEI company, Hillsboro, OR, USA). 


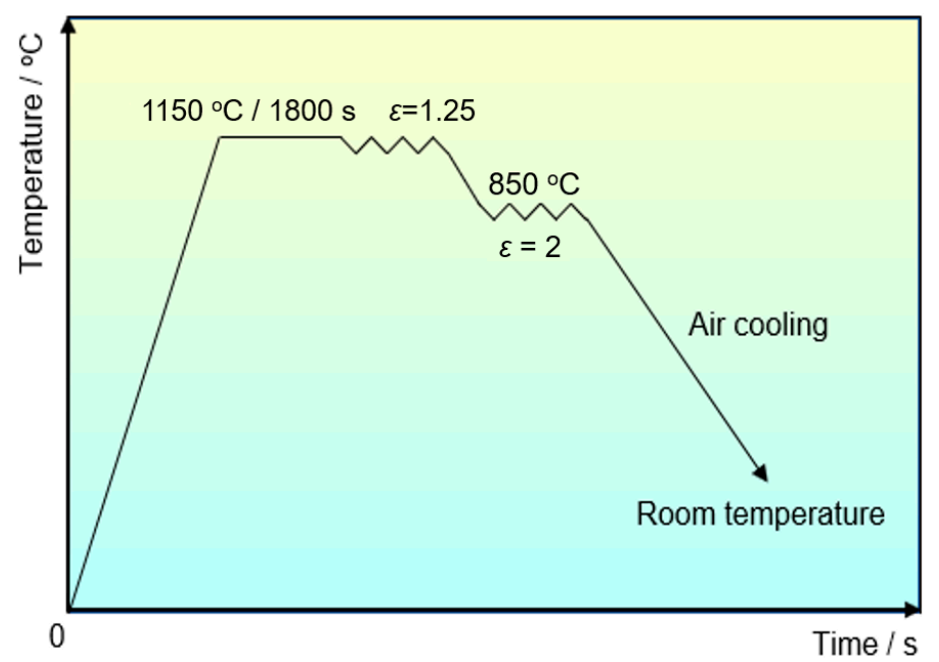

Figure 1. Forging process and the corresponding parameters for experimental steels.

\section{Results and Discussion}

Figure 2 illustrates typical transmission electron microscope (TEM) images obtained from carbon extraction replicas showing the morphology and size of the precipitates in steel S1 and S2 after hot forging. It can be seen that some precipitates were randomly dispersed in both steels. Compared to those in steel S1 (Figure 2a), the precipitates in steel S2 (Figure $2 b$ ) have relatively small sizes and are more uniform throughout the matrix.
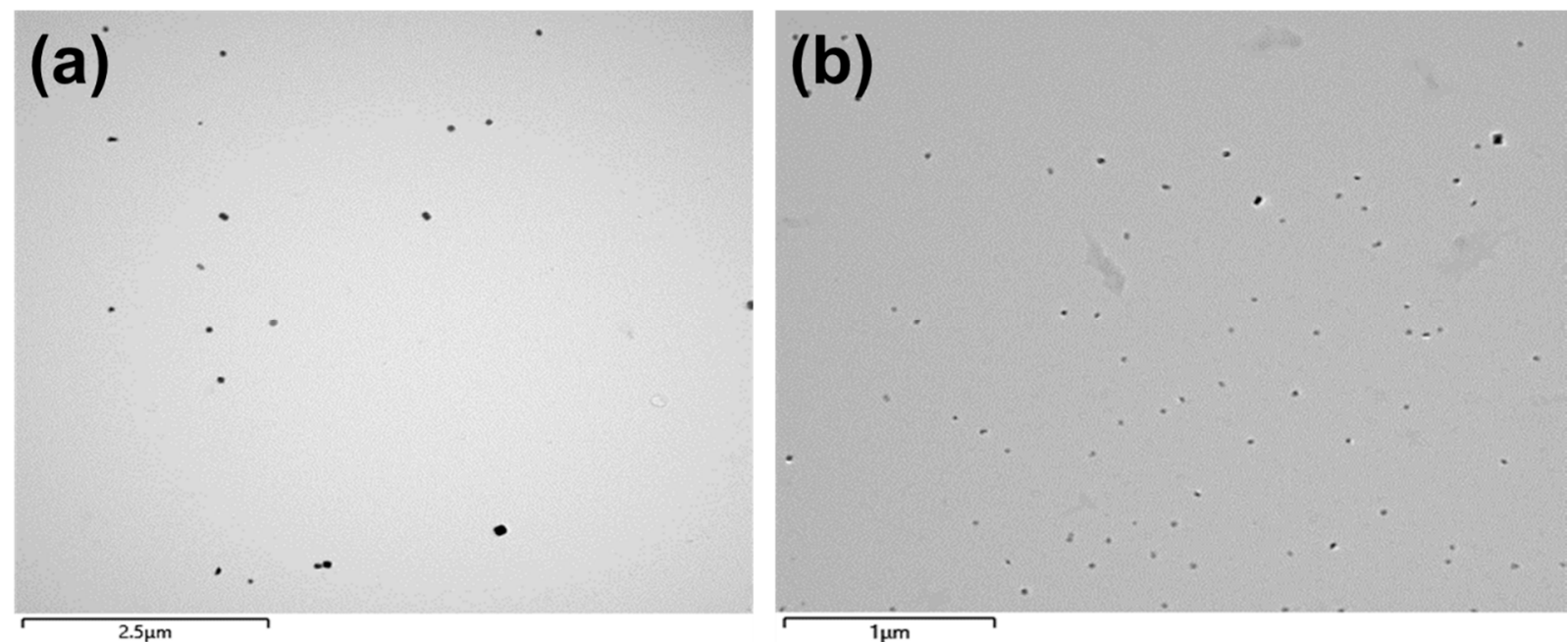

Figure 2. TEM images obtained from carbon extraction replicas showing the precipitates in the studied steels after hot forging: (a) steel S1; (b) steel S2.

A high-resolution TEM image of random precipitates in steel S1 is shown in Figure 3. It is seen that the precipitates in steel S1 are mainly spherical with a size of approximately $50 \mathrm{~nm}$. A further Energy Dispersive Spectroscopy (EDS) analysis of the composition distribution in this precipitate illustrates that the particle is mainly composed of $\mathrm{Nb}$ and a small amount of $\mathrm{V}$ and Ti elements. All the precipitates in Figure 2a were measured by EDS analysis, and the corresponding chemical compositions for each precipitate are summarized in Table 2. It should be noted that there is always a certain amount of $\mathrm{Cu}$ element for each precipitate according to the EDS results, which is caused by the copper grid supporting the carbon film. The $\mathrm{Cu}$ content in each precipitate is not shown in Table 2. 

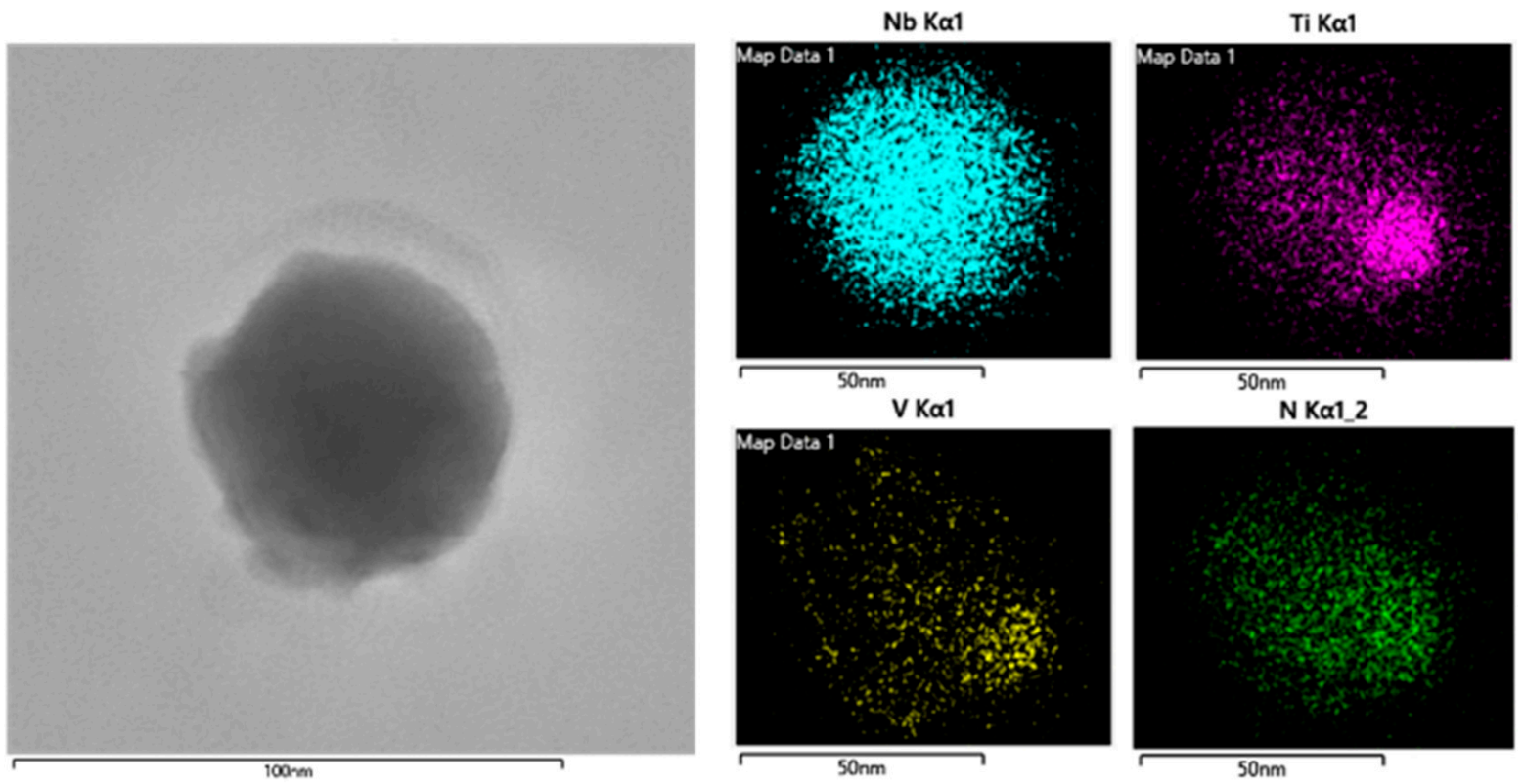

Figure 3. TEM image showing the morphology and the $\mathrm{Ti} / \mathrm{Nb} / \mathrm{V}$ distribution in a random precipitate in steel S1.

Table 2. Analysis of particle size and the contents of $\mathrm{Nb} / \mathrm{V} / \mathrm{Ti}$ elements in those precipitates in Figure 2a (steel S1).

\begin{tabular}{ccccc}
\hline Class & ECD $(\boldsymbol{\mu m})$ & Ti $(w t . \%)$ & V (wt.\%) & Nb (wt.\%) \\
\hline $\mathrm{TiVNb}$ & 0.061678 & 2.916971 & 1.943436 & 59.36655 \\
$\mathrm{VNb}$ & 0.09212 & - & 1.024304 & 1.433306 \\
$\mathrm{TiVNb}$ & 0.092586 & 4.130418 & 1.924443 & 57.43785 \\
$\mathrm{TiVNb}$ & 0.064408 & 1.74785 & 2.035784 & 54.06454 \\
$\mathrm{VNb}$ & 0.065468 & - & 2.897306 & 49.08118 \\
$\mathrm{VNb}$ & 0.062784 & - & 4.321418 & 46.55011 \\
$\mathrm{TiVNb}$ & 0.070164 & 1.636067 & 1.092925 & 59.78169 \\
$\mathrm{TiVNb}$ & 0.056887 & 1.221049 & 1.176167 & 60.00959 \\
$\mathrm{TiVNb}$ & 0.086033 & 1.787149 & 1.115035 & 63.06081 \\
$\mathrm{TiVNb}$ & 0.070653 & 1.356135 & 1.294701 & 54.77613 \\
$\mathrm{TiVNb}$ & 0.057638 & 1.54289 & 1.727562 & 51.45393 \\
$\mathrm{TiVNb}$ & 0.062647 & 1.074376 & 3.604971 & 49.94766 \\
$\mathrm{TiVNb}$ & 0.068927 & 2.083507 & 1.738859 & 49.53244 \\
$\mathrm{TiVNb}$ & 0.047122 & 1.339961 & 2.881639 & 40.23057 \\
\hline
\end{tabular}

It can be seen from Table 2 that almost all the precipitates in steel S1 are composed of $\mathrm{Nb}, \mathrm{V}$ and Ti elements, although the contents of $\mathrm{V}$ and Ti elements usually have a relatively low value in these precipitates, even if there are three particles without Ti elements. Generally, the relative atomic weights of $\mathrm{Nb}, \mathrm{V}$ and Ti elements are 92.9, 50.9 and 47.9, respectively. Assuming that the particles are the complex carbonitrides of $\mathrm{Nb} / \mathrm{V} / \mathrm{Ti}$, the composition ratio for each element should be close to 2:1:1 in a random precipitate. However, based on the analysis results by TEM and EDS, as shown in Table 2, it can be found that the $\mathrm{Nb}$ contents in most precipitates are larger than $40 \%$, while the contents of $\mathrm{Ti}$ and $\mathrm{V}$ are both less than $5 \%$ in steel $\mathrm{S} 1$. It is reasonable to conclude that the particles are dominantly $\mathrm{Nb}(\mathrm{C}$, $\mathrm{N})$ precipitates with small amounts of Ti and V solutes. As mentioned above, Ti element clustered in these precipitates in steel S1 should be a residual element during steel-making. Research based on thermodynamic and kinetic theoretical analyses $[13,19]$ shows that there is a considerable binding ability between $\mathrm{Ti}$ and $\mathrm{N}$ elements, and that there is a strong tendency to form TiN particles, even if the content of Ti element is very low. 
The same analyses are carried out for steel S2 with $0.009 \mathrm{wt} \% \mathrm{Ti}$ addition. The typical morphology of a random precipitate in Figure $2 b$ and its corresponding composition distribution are shown in Figure 4. As seen from Figure 4, the precipitate in steel S2 exhibits a complex structural feature, i.e., a $\mathrm{NbC}$ hemispherical cap was attached to a TiN cuboid core, as reported in previous work [18]. As known, TiN particles are usually formed at an elevated temperature compared to $\mathrm{NbC}$ particles. During the hot working and/or subsequent cooling process, extensive $\mathrm{NbC}$ particles would heterogeneously nucleate along the pre-formed TiN particles and then formed complex TiN-NbC particles.

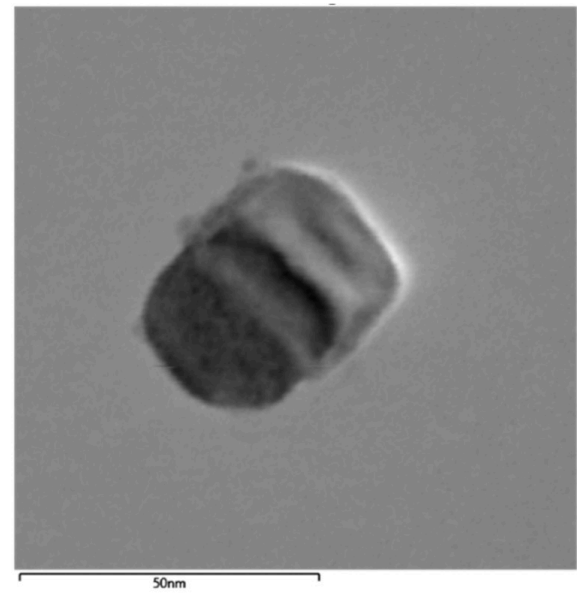

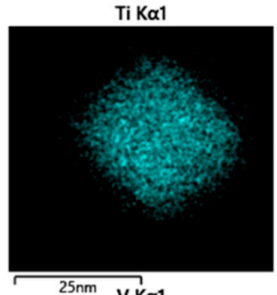

${ }^{25 n m} \quad \mathrm{~V} \mathrm{K \alpha} 1$

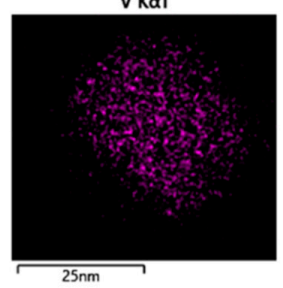

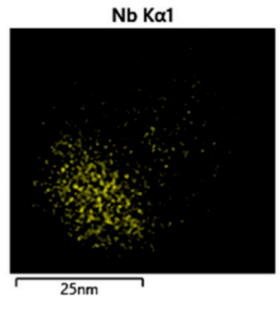

$25 \mathrm{~nm}$

Figure 4. Morphology and corresponding composition distribution of $\mathrm{Nb} / \mathrm{V} / \mathrm{Ti}$ in a random precipitate in Figure $2 b$.

The detailed analyses for the composition of all the precipitates in Figure $2 \mathrm{~b}$ are summarized in Table 3. As can be seen, almost all the precipitates are composed of $\mathrm{Nb}, \mathrm{V}$ and $\mathrm{Ti}$ elements, except for two TiN particles. In particular, the proportion of Ti content in each precipitate is significantly higher than that in steel S1. Therefore, combined with the morphology observation in Figure 3, it can be concluded that the TiN-NbC complex particles are the dominant feature in the Ti-microalloyed steel. Obviously, the nucleation mechanism of precipitates in steel S2 is significantly different from that in steel S1; that is, the dominant mechanism for $\mathrm{NbC}$ particles in Ti-free steel is strain-induced precipitates, while epitaxial growth occurs in $\mathrm{NbC}$ on TiN particles in Ti-microalloyed steel. It is noteworthy that this epitaxial growth mechanism exhibits great potential value in the microstructure control of heavy structural steels, because their limited reduction ratio strongly restrains the advantage of strain-induced $\mathrm{NbC}$ precipitation.

A further analysis based on the morphology of the particles in Figure 4 shows that the TiN core has a size of approximately $25 \mathrm{~nm}$, and that the size of the complex TiN-NbC particle is approximately $40 \mathrm{~nm}$. The size of each precipitate observed in Figure $2 \mathrm{~b}$ (steel S2) can also be found in Table 3. Comparing the values of particle size in Tables 2 and 3, it can be found that the particle size in steel S2 is significantly smaller than that in steel S1, which agrees well with the morphology observation in Figure 2. To better understand the influence of Ti microalloying on the size and type of precipitates, a more accurate description based on statistical analysis of more particles is necessary. Several images were taken continuously from the carbon extraction replicas of both steels, and the particle size and composition were analyzed, respectively.

For steel S1, 11 images with a scanning area of $7.6 \mu \mathrm{m} \times 7.2 \mu \mathrm{m}$ were obtained from TEM observations, in which a total of 81 particles were found, and the corresponding results, including precipitate size and composition, are summarized in Table 4 . The precipitate sizes ranged from 9.3 to $121.8 \mathrm{~nm}$, and the average size of all precipitates was $54.1 \mathrm{~nm}$. The distribution of the precipitates in steel S1, as shown in Figure 5, illustrates that the particles with a size of approximately $60 \mathrm{~nm}$ have the largest proportion and that approximately $15 \%$ of precipitates have a size larger than $80 \mathrm{~nm}$. 
Table 3. Measurement of size and the corresponding element contents for each particle in Figure $2 b$ (steel S2).

\begin{tabular}{|c|c|c|c|c|}
\hline Class & $\operatorname{ECD}(\mu \mathrm{m})$ & Ti (wt.\%) & V (wt.\%) & $\mathrm{Nb}$ (wt.\%) \\
\hline $\mathrm{TiVNb}$ & 0.0338 & 20.42 & 4.30 & 40.30 \\
\hline $\mathrm{TiVNb}$ & 0.0324 & 13.21 & 3.24 & 43.05 \\
\hline $\mathrm{TiVNb}$ & 0.0256 & 15.82 & 5.26 & 40.26 \\
\hline $\mathrm{TiVNb}$ & 0.0298 & 15.81 & 4.34 & 35.67 \\
\hline $\mathrm{TiVNb}$ & 0.0401 & 22.25 & 3.67 & 40.63 \\
\hline $\mathrm{TiVNb}$ & 0.0266 & 8.75 & 2.69 & 41.18 \\
\hline $\mathrm{TiVNb}$ & 0.0222 & 13.57 & 5.16 & 28.19 \\
\hline $\mathrm{TiVNb}$ & 0.0255 & 12.67 & 5.56 & 38.87 \\
\hline $\mathrm{TiVNb}$ & 0.0272 & 16.04 & 4.93 & 31.57 \\
\hline $\mathrm{TiVNb}$ & 0.0235 & 14.32 & 5.25 & 32.04 \\
\hline $\mathrm{TiVNb}$ & 0.0243 & 12.40 & 5.47 & 28.69 \\
\hline $\mathrm{TiVNb}$ & 0.0271 & 8.61 & 3.15 & 41.19 \\
\hline $\mathrm{TiVNb}$ & 0.0298 & 16.72 & 4.89 & 30.29 \\
\hline $\mathrm{TiVNb}$ & 0.0274 & 8.81 & 4.18 & 41.79 \\
\hline $\mathrm{TiVNb}$ & 0.0298 & 16.89 & 5.96 & 29.86 \\
\hline $\mathrm{TiVNb}$ & 0.0327 & 11.44 & 4.56 & 33.77 \\
\hline $\mathrm{TiVNb}$ & 0.0250 & 13.39 & 6.17 & 28.91 \\
\hline $\mathrm{TiN}$ & 0.0319 & 4.57 & - & - \\
\hline TiN & 0.0287 & 5.88 & - & - \\
\hline
\end{tabular}

Table 4. Statistical analyses of the size and composition of precipitates in steel S1.

\begin{tabular}{|c|c|c|c|c|c|c|}
\hline No & Number & Category & $\operatorname{Size}(\mu \mathrm{m})$ & Ti (wt.\%) & V (wt.\%) & $\mathrm{Nb}(w t . \%)$ \\
\hline \multirow{3}{*}{1} & \multirow{3}{*}{9} & Min & 0.0093 & 0 & 0.065 & 0 \\
\hline & & Max & 0.1076 & 3.423 & 12.321 & 65.854 \\
\hline & & Mean & 0.0748 & 1.716 & 3.085 & 48.450 \\
\hline \multirow{3}{*}{2} & \multirow{3}{*}{14} & Min & 0.0471 & 0 & 1.093 & 1.433 \\
\hline & & Max & 0.0926 & 4.130 & 4.321 & 63.061 \\
\hline & & Mean & 0.0685 & 1.488 & 2.055 & 49.766 \\
\hline \multirow{3}{*}{3} & \multirow{3}{*}{7} & Min & 0.0535 & 1.372 & 1.042 & 59.221 \\
\hline & & Max & 0.0757 & 3.772 & 2.031 & 66.196 \\
\hline & & Mean & 0.0662 & 2.837 & 1.369 & 62.549 \\
\hline \multirow{3}{*}{4} & \multirow{3}{*}{5} & Min & 0.0380 & 1.562 & 1.057 & 49.157 \\
\hline & & Max & 0.0762 & 5.421 & 2.353 & 60.091 \\
\hline & & Mean & 0.0648 & 3.589 & 1.457 & 56.521 \\
\hline \multirow{3}{*}{5} & \multirow{3}{*}{6} & Min & 0.0550 & 0 & 1.223 & 39.416 \\
\hline & & Max & 0.0827 & 8.229 & 2.625 & 56.854 \\
\hline & & Mean & 0.0692 & 4.380 & 1.733 & 48.848 \\
\hline \multirow{3}{*}{6} & \multirow{3}{*}{9} & Min & 0.0117 & 2.699 & 0 & 0 \\
\hline & & Max & 0.0841 & 40.391 & 4.261 & 60.992 \\
\hline & & Mean & 0.0367 & 15.991 & 1.464 & 42.004 \\
\hline \multirow{3}{*}{7} & \multirow{3}{*}{17} & Min & 0.0195 & 1.089 & 1.005 & 39.128 \\
\hline & & Max & 0.1218 & 32.832 & 9.138 & 62.216 \\
\hline & & Mean & 0.0438 & 11.343 & 3.053 & 47.082 \\
\hline \multirow{3}{*}{8} & \multirow{3}{*}{3} & Min & 0.0117 & 2.991 & 1.991 & 39.755 \\
\hline & & Max & 0.0489 & 16.257 & 4.665 & 57.554 \\
\hline & & Mean & 0.0344 & 9.150 & 3.698 & 47.648 \\
\hline \multirow{3}{*}{9} & \multirow{3}{*}{2} & Min & 0.0327 & 2.944 & 1.118 & 49.830 \\
\hline & & Max & 0.0834 & 16.450 & 2.620 & 57.645 \\
\hline & & Mean & 0.0580 & 9.697 & 1.869 & 53.734 \\
\hline 10 & 1 & - & 0.0256 & 18.88 & 1.992 & 48.615 \\
\hline \multirow{3}{*}{11} & \multirow{3}{*}{8} & Min & 0.0138 & 0 & 1.095 & 6.650 \\
\hline & & Max & 0.0282 & 38.829 & 5.628 & 55.818 \\
\hline & & Mean & 0.0285 & 10.921 & 2.843 & 41.572 \\
\hline
\end{tabular}




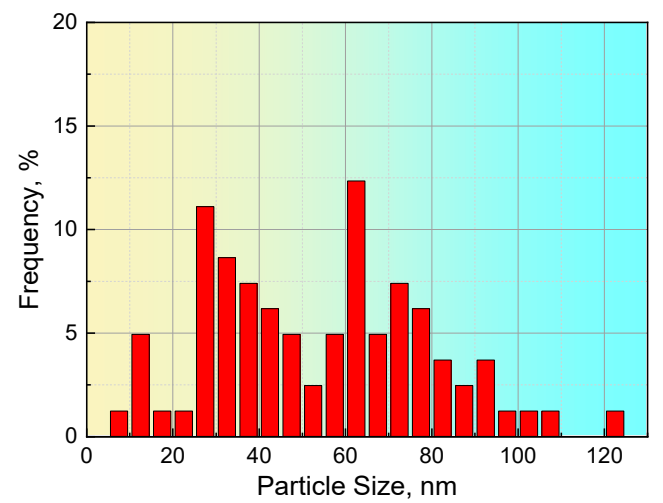

Figure 5. Distribution of the size of the precipitates in steel S1.

The McCall-Boyd method is usually used to determine the volume fraction of the second phase particles, and can be calculated as indicated by Equation (1) [20,21]:

$$
V_{f}=\left(\frac{1.4 \pi}{6}\right) \times\left(\frac{N D_{\text {mean }}^{3}}{A D_{\max }}\right)
$$

where $D_{\text {mean }}$ and $D_{\text {max }}$ are the average diameter and the maximum diameter of particles, respectively, $N$ is the number of particles and $A$ is the total observation area containing those measured particles. According to Equation (1) and the statistical data for steel S1, it should be noted that the volume fraction of $\mathrm{NbC}$ precipitates is approximately $0.0128 \%$ for steel S1.

In general, the equilibrium solubility for $\mathrm{Nb}$ and $\mathrm{C}$ atoms in the matrix strongly depends on temperature and can be expressed as follows [22]:

$$
\log [N b][C]=3.72-\frac{8534}{T}
$$

where $[\mathrm{Nb}]$ and $[\mathrm{C}]$ are the concentrations of $\mathrm{Nb}$ and $\mathrm{C}$, respectively, and $\mathrm{T}$ is the temperature. For steel S1 with 0.18 wt. $\% \mathrm{C}$ and $0.031 \mathrm{wt} . \% \mathrm{Nb}$, the volume fraction of $\mathrm{NbC}$ precipitates depending on the temperature is illustrated in Figure 6. The maximum volume fraction of $\mathrm{NbC}$ precipitates reached approximately $0.0345 \%$ S1 when steel S1 was compressed at $850{ }^{\circ} \mathrm{C}$ and then cooled to room temperature. This deviation between the experimental and calculated values suggests that the precipitation of $\mathrm{NbC}$ particles could not be completed kinetically under the current forge processing. The primary reason for this incomplete precipitation can be attributed to low strain accumulation; that is, the strain accumulation during forge processing is not large enough to stimulate the straininduced precipitation mechanism, and results in only approximately $37 \%$ of $\mathrm{NbC}$ particles precipitated from the matrix.

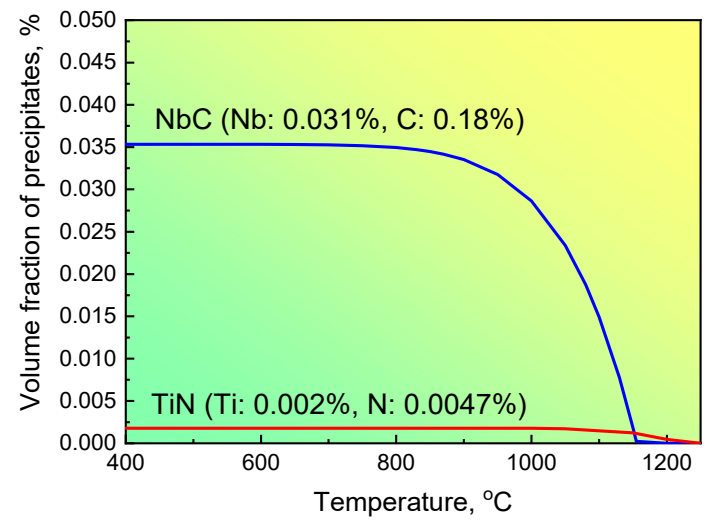

Figure 6. The precipitation of $\mathrm{NbC}$ changed with different temperatures for steel S1. 
For steel S2, 356 particles were achieved based on six images with a scanning area of $3.8 \mu \mathrm{m} \times 3.6 \mu \mathrm{m}$. The statistical results in Table 5 show that the particle size in steel S2 is in the range from 4.6 to $54.7 \mathrm{~nm}$, and that the average size of the particles is approximately $25.4 \mathrm{~nm}$. The distribution of the precipitate size in steel S2 is described in Figure 7. Approximately $85 \%$ of the precipitates had a size less than $30 \mathrm{~nm}$. The application of these values to Equation (1) shows that the volume fraction of precipitates in steel S2 is approximately $0.095 \%$ based on the experimental observations.

Table 5. Statistical analyses of the size and composition of precipitates in steel S2.

\begin{tabular}{|c|c|c|c|c|c|c|}
\hline No & Number & Category & Size $(\mu \mathrm{m})$ & Ti (wt. \%) & V (wt. \%) & $\mathrm{Nb}(w \mathrm{t} . \%)$ \\
\hline \multirow{3}{*}{1} & \multirow{3}{*}{23} & Min & 0.0055 & 4.478 & 0 & 0 \\
\hline & & Max & 0.0402 & 38.839 & 8.337 & 50.396 \\
\hline & & Mean & 0.0240 & 13.503 & 4.161 & 27.137 \\
\hline \multirow{3}{*}{2} & \multirow{3}{*}{51} & Min & 0.0169 & 2.691 & 0 & 0 \\
\hline & & Max & 0.0547 & 33.021 & 6.297 & 43.046 \\
\hline & & Mean & 0.0288 & 11.577 & 3.705 & 25.912 \\
\hline \multirow{3}{*}{3} & \multirow{3}{*}{62} & Min & 0.0138 & 7.155 & 1.709 & 20.783 \\
\hline & & Max & 0.0507 & 34.159 & 7.276 & 46.006 \\
\hline & & Mean & 0.0270 & 15.276 & 5.017 & 34.843 \\
\hline \multirow{3}{*}{4} & \multirow{3}{*}{77} & Min & 0.0046 & 0 & 0 & 2.861 \\
\hline & & Max & 0.0363 & 23.357 & 7.132 & 42.568 \\
\hline & & Mean & 0.0241 & 12.880 & 4.846 & 32.551 \\
\hline \multirow{3}{*}{5} & \multirow{3}{*}{91} & Min & 0.0059 & 7.503 & 3.751 & 22.347 \\
\hline & & Max & 0.0363 & 26.323 & 7.938 & 45.037 \\
\hline & & Mean & 0.0234 & 14.438 & 5.178 & 35.593 \\
\hline \multirow{3}{*}{6} & \multirow{3}{*}{52} & Min & 0.0162 & 5.180 & 2.936 & 19.270 \\
\hline & & Max & 0.0393 & 21.630 & 7.172 & 40.043 \\
\hline & & Mean & 0.0254 & 13.561 & 4.691 & 30.488 \\
\hline
\end{tabular}

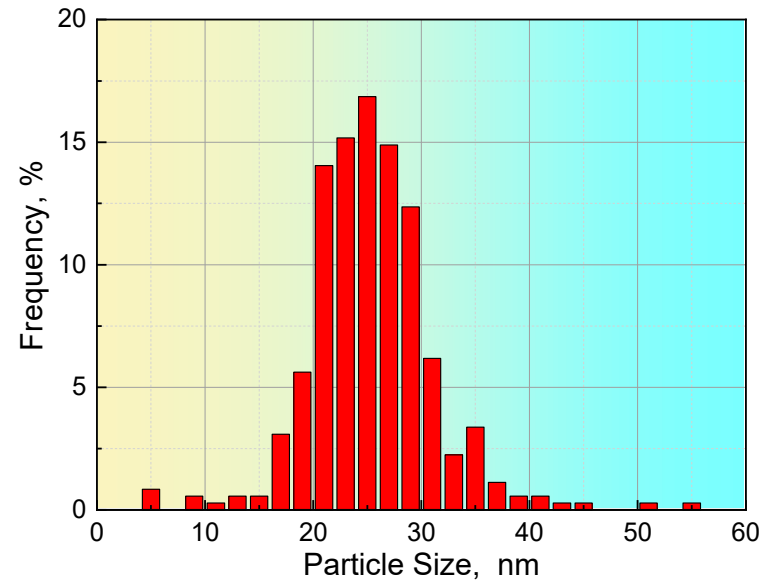

Figure 7. Distribution of the size of the precipitates in steel S2.

As mentioned above, TiN particles are usually precipitated at a high temperature, and then would provide nuclei for the epitaxial growth of $\mathrm{NbC}$ particles. The solubility products of TiN in austenite can be described as previously reported [23] in Equation (3)

$$
\log [T i][N]=4.94-\frac{14400}{T}
$$

where [Ti] and [N] are equilibrium concentrations of $\mathrm{Ti}$ and $\mathrm{N}$ at a temperature of $T$. The precipitation of $\mathrm{NbC}$ and TiN particles in steel $\mathrm{S} 2$ at different temperatures is calculated according to Equations (2) and (3), and the corresponding results are shown in Figure 8. 
The calculated [Ti] and [N] values at $1150{ }^{\circ} \mathrm{C}$ are 0.0012 and 0.0023 , respectively. Thus, the volume fraction of TiN particles at this temperature is approximately $0.007 \%$. When steel $\mathrm{S} 2$ is subjected to a subsequent compression at $850{ }^{\circ} \mathrm{C}$, the volume fraction of TiN tends to be slightly increased to $0.008 \%$. Meanwhile, $\mathrm{NbC}$ begins to precipitate, and the maximum volume fraction of $\mathrm{NbC}$ calculated according to Equation (2) is $0.042 \%$ at this condition. Therefore, the total fraction of precipitates in steel S2 is $0.050 \%$. It is noted that this is a smaller value than that obtained from experimental observations. The possible reason for this difference might be the fact that there are actually some different types of precipitates, including $\mathrm{Ti}$ and $\mathrm{Nb}$ carbonitrides and/or $\mathrm{V}(\mathrm{C}, \mathrm{N})$, in the microalloyed steel, not just TiN and $\mathrm{NbC}$ particles. On the other hand, due to the complex structure characterized by the TiN cuboid core and $\mathrm{NbC}$ hemispherical cap, the statistics regarding their sizes may not be accurate, resulting in a larger value of the volume fraction of precipitates calculated based on Equation (1). The detailed reasons will be investigated in our future work.

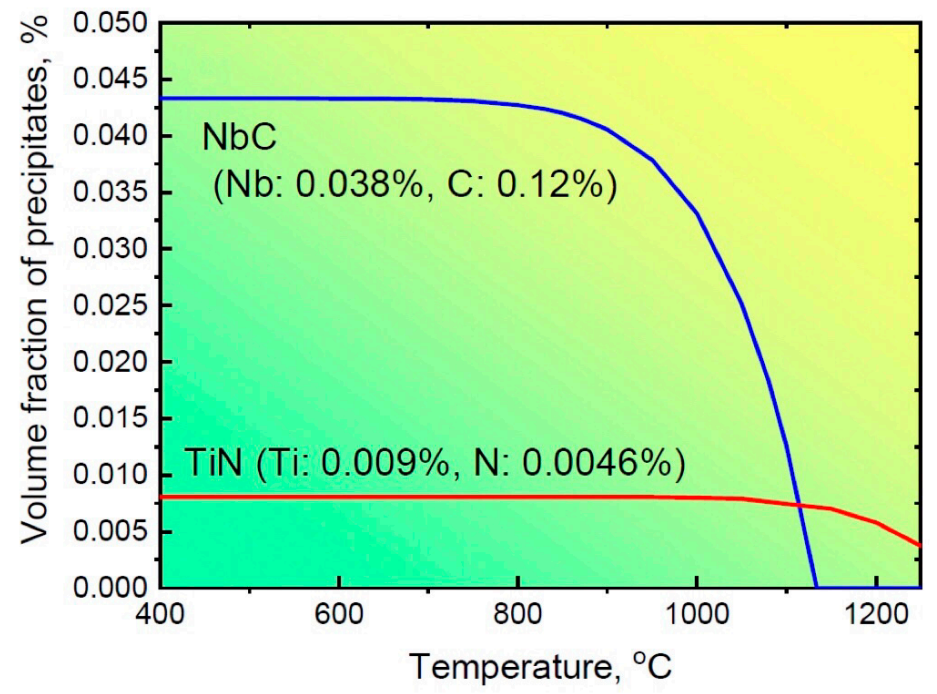

Figure 8. The precipitation of $\mathrm{NbC}$ and TiN particles changed with different temperatures for steel S2.

The above results clearly show that the average size of the complex TiN-NbC precipitates in steel S2 is less than that of the $\mathrm{NbC}$ precipitates in steel S1, while the volume fraction of precipitates in steel S2 is significantly larger than that in steel S1. Although there is an obvious difference in $\mathrm{Nb}$ and $\mathrm{C}$ contents between steel $\mathrm{S} 1$ and $\mathrm{S} 2$, it has no significant effect on the amount of $\mathrm{NbC}$ precipitates $\left(0.0345 \%\right.$ vs. $0.0420 \%$ at $\left.850{ }^{\circ} \mathrm{C}\right)$. Therefore, it can be confirmed that Ti microalloying is the factor most directly responsible for the difference in the size and quantity of precipitates between the two steels. The Ti addition and the resulting TiN particles may provide abundant nuclei for $\mathrm{NbC}$ particles and then accelerate $\mathrm{NbC}$ precipitation. In this event, $\mathrm{NbC}$ precipitation no longer required nucleation, but only epitaxial growth attached to TiN particles. These extensive pre-existing TiN particles make the precipitation of $\mathrm{NbC}$ particles more dispersed, and these $\mathrm{NbC}$ precipitates attached to TiN particles would consume a majority of $\mathrm{Nb}$ atoms in the matrix, which effectively reduces the driving force for the coarsening of $\mathrm{NbC}$ particles. Therefore, the mechanism of epitaxial growth of $\mathrm{NbC}$ on pre-existing $\mathrm{TiN}$ is usually conducive to the formation of fine and dispersed complex particles. In other words, $\mathrm{NbC}$ precipitation in Ti-microalloyed steels does not need to be strongly dependent on large strain accumulation, i.e., the straininduced precipitation mechanism. This result suggests that it is more profitable to control the microstructure in heavy structural steels with limited reduction during hot rolling by $\mathrm{Ti}$ microalloying; for example, finer and more dispersed particles will play an important role in suppressing static recrystallization during the pass interval of finishing rolling. 


\section{Conclusions}

(1) $\mathrm{Ti}$ addition changes the precipitation mechanism of $\mathrm{NbC}$ particles in $\mathrm{Nb}$-microalloyed steels. Nucleation and subsequent growth are the dominant precipitation mechanisms of $\mathrm{NbC}$ particles in $\mathrm{Nb}$-microalloyed steel, while they change to epitaxial growth of $\mathrm{NbC}$ particles attached to pre-existing TiN in Ti-Nb-microalloyed steel.

(2) The average size of the $\mathrm{NbC}$ precipitates is $54.1 \mathrm{~nm}$, and the volume fraction is $0.0128 \%$ in $\mathrm{Nb}$-microalloyed steel, while the corresponding values are $25.4 \mathrm{~nm}$ and $0.095 \%$, respectively, in Ti-Nb-microalloyed steel. That is, the complex structure of TiN-NbC particles usually has a smaller size and more dispersed distribution in Ti-Nb-microalloyed steel than in $\mathrm{Nb}$-microalloyed steel.

(3) $\mathrm{NbC}$ particles may not be completely precipitated via a strain-induced precipitation mechanism, especially when the strain accumulation is not large enough, while Ti addition can effectively promote the precipitation of $\mathrm{NbC}$ particles.

Author Contributions: Conceptualization, G.Z.; methodology, B.W.; formal analysis, J.X. and G.Z.; investigation, J.X., H.D. and H.P.; resources, B.W. and H.P.; data curation, H.D.; writing - original draft preparation, J.X.; writing-review and editing, G.Z. and H.D.; project administration, G.Z.; funding acquisition, H.D. All authors have read and agreed to the published version of the manuscript.

Funding: This work was financially supported by the National Natural Science Foundation of China (52174367).

Data Availability Statement: The raw data required to reproduce these findings cannot be shared at this time, as the data also form part of an ongoing study.

Acknowledgments: The authors are grateful for experimental support from Maanshan Iron \& Steel Co., Ltd. The authors are thankful to Q.W. Chen and Y.Q. Wang at Anhui University of Technology for helpful discussion.

Conflicts of Interest: The authors declare no conflict of interest.

\section{References}

1. Gu, L.H.; Li, S.L.; Liu, C.M.; Liu, J.G.; Zhang, S.Y.; Chu, R.S.; Ma, C.W. Development and application of super heavy gauge high-strength structural steel for high-rise buildings. IOP Conf. Ser. Mate. Sci. Eng. 2017, 242, 012062. [CrossRef]

2. Samie, N.N. Disciplines involved in offshore platform design. In Practical Engineering Management of Offshore Oil and Gas Platforms; Gulf Professional Publishing: Cambridge, MA, USA, 2016; pp. 25-212. [CrossRef]

3. Wang, B.; Wang, Z.D.; Wang, B.X.; Wang, G.D.; Misra, R.D.K. The relationship between microstructural evolution and mechanical properties of heavy plate of low-Mn steel during ultra fast cooling. Metall. Mater. Trans. A 2015, 46, 2834-2843. [CrossRef]

4. Kitani, Y.; Ikeda, R.; Ono, M.; Ikeuchi, K. Improvement of Weld Metal Toughness in High Heat Input Electro-Slag Welding of Low Carbon Steel, Weld. World 2009, 53, R57-R63. [CrossRef]

5. Yoon, J.I.; Jung, J.; Joo, S.H.; Song, T.J.; Chin, K.G.; Seo, M.H.; Kim, S.J.; Lee, S.; Kim, H.S. Correlation between fracture toughness and stretch-flangeability of advanced high strength steels. Mater. Lett. 2016, 180, 322-326. [CrossRef]

6. Todic, A.; Cikara, D.; Todic, T.; Cikara-Anic, D.; Minic, D. Influence of chemical composition on the structure, hardness and toughness of high alloyed Cr-Mo-V steel. Mater. Manuf. Process. 2012, 27, 1193-1197. [CrossRef]

7. Pourazizi, R.; Davani, R.K.Z.; Mohtadi-Bonab, M.A.; Szpunar, J.A. Evolution of microstructure and texture in pipeline steels at different TMCP procedures with regard to hydrogen induced cracking. Int. J. Hydrogen Energy 2021, 46, 38741-38754. [CrossRef]

8. El-Shenawy, E.; Reda, R. Optimization of TMCP strategy for microstructure refinement and flow-productivity characteristics enhancement of low carbon steel. J. Mater. Res. Technol. 2019, 8, 2819-2831. [CrossRef]

9. Zhu, G.; Subramanian, S.V. Ultra-fine grain size control and mixed grains elimination in industrial multi-pass rolling processing. Mater. Sci. Eng. A 2006, 426, 235-239. [CrossRef]

10. Zhu, G.H.; Subramanian, S.V. Recrystallization behavior design for controlling grain size in strip rolling process. J. Iron Steel Res. Int. 2008, 15, 39-44. [CrossRef]

11. Ding, H.L.; Zhu, G.H.; Chen, Q.W.; Wang, Y.Q.; Wang, X.N. Mechanism of boundary induced transformation and its application in the grain refinement of large-size structural steels. Mater. Sci. Eng. A 2021, 818, 141342. [CrossRef]

12. Wang, Y.; Li, J.; Li, F.; Ge, Z.; Xing, J.; Li, N.; Zhu, G.; Ding, H.; Chen, Q. The important role of titanium microalloying in refining austenite grain of heavy-duty H-beam steel during rough rolling produced by a new technology. Mater. Sci. Eng. Technol. 2021, 52, 781-791. [CrossRef]

13. Capurro, C.; Cicutti, C. Analysis of titanium nitrides precipitated during medium carbon steels solidification. J. Mater. Res. Technol. 2018, 7, 342-349. [CrossRef] 
14. Xing, L.; Guo, J.; Li, X.; Zhang, Z.; Wang, M.; Bao, Y. Control of TiN precipitation behavior in titanium-containing micro-alloyed steel. Mater. Today Commun. 2020, 25, 101292. [CrossRef]

15. Moon, J.; Lee, C.; Uhm, S.; Lee, J. Coarsening kinetics of TiN particle in a low alloyed steel in weld HAZ: Considering critical particle size. Acta Mater. 2006, 54, 1053-1061. [CrossRef]

16. Medina, S.; Chapa, M.; Valles, P.; Ouispe, A.; Vega, M. Influence of Ti and N contents on austenite grain control and precipitate size in structural steels. ISIJ Int. 1999, 39, 930-936. [CrossRef]

17. Craven, A.J.; He, K.; Garvie, L.A.J.; Baker, T.N. Complex heterogeneous precipitation in titanium-niobium microalloyed Al-killed HSLA steels-I. (Ti,Nb)(C,N) particles. Acta Mater. 2000, 48, 3857-3868. [CrossRef]

18. Ma, X.; Miao, C.; Langelier, B.; Subramanian, S. Suppression of strain-induced precipitation of NbC by epitaxial growth of NbC on pre-existing TiN in Nb-Ti microalloyed steel. Mater. Design. 2017, 132, 244-249. [CrossRef]

19. Gui, L.; Long, M.; Zhang, H.; Chen, D.; Liu, S.; Wang, Q.; Duan, H. Study on the precipitation and coarsening of TiN inclusions in Ti-microalloyed steel by a modified coupling model. J. Mater. Res. Technol. 2020, 9, 5499-5514. [CrossRef]

20. McCall, J.L.; Boyd, J.E. Quantitative metallography of dispersion-strengthened alloys from extraction replicas-volume fraction and interparticle spacing. In Proceedings of the First Annual Technical Meeting of the International Metallographic Society, Denver, CO, USA, 8 September 1969; pp. 153-155.

21. Seher, R.J.; Maniar, G.N. Analytical-preshadowed extraction replica technique. Metallography 1972, 5, 409-414. [CrossRef]

22. Matsuda, S.; Okumura, N. Effect of distribution of TiN precipitate particles on the austenite grain size of low carbon low alloy steels. ISIJ Int. 1978, 18, 198-205. [CrossRef]

23. Wada, H.; Pehlke, R.D. Nitrogen solubility and nitride formation in austenitic Fe-Ti alloys. Metall. Mater. Trans. B 1985, 16, 815-822. [CrossRef] 